\title{
Sensitization to and Conditioning With Apomorphine in Pigeons
}

\author{
BRIGITTE BURG, ${ }^{*}$ CHRISTIAN HAASE, $\dagger$ ULRIKE LINDENBLATT $\dagger$ \\ AND JUAN D DELIUS*1 \\ *Allgemeine Psychologie, Universitat Konstanz, D 7750 Konstanz, FRG \\ and TPsychologisches Institut, Ruhr-Universitat Bochum, D 4630 Bochum, FRG
}

\begin{abstract}
BURG, B , C HAASE, U LINDENBLATT AND J D DELIUS Sensinzation to and condinoning with apomorphine in pigeons PHARMACOL BIOCHEM BEHAV 34(1) 59-64, 1989 -Pigeons that repeatedly expenenced the effect of apomorphine in the same environment showed an augmented behavioural response to the same drug dose as compared with controls that expernenced the effect of the drug dose in differing environments Sensitization, an increase in the behavioural response that is observed in pigeons when the same dose of apomorphine is repeatedly administered, may thus be mainly due to a conditioning of the drug response to incidental environmental cues Apomorphine injections also induced place preferences Pigeons that had experienced a particular environment under the influence of apomorphine subsequently favoured that environment to one they had experienced while under salıne This suggests that apomorphine administration has reinforcing properties for birds, much as it has for mammals
\end{abstract}

Pigeon Apomorphine Dopamine Conditioning Reinforcement Sensitızation Tolerance

APOMORPHINE, a potent dopamine agonist, has long been known to elicit protracted pecking in birds $(1,5,14)$ Pigeons begin to peck within a few minutes after an intramuscular (IM) injection of an optımally effectıve dose of about $1 \mathrm{mg} / \mathrm{kg}$ apomorphine They contınue to peck for nearly $90 \mathrm{~min}$, reaching a maximum rate of about 150 responses/min some $10 \mathrm{~min}$ after injection and peck altogether several thousand times In comparable circumstances, control, salıne-ınjected pigeons peck on average less than once (7) Even though the burds do not normally swallow grain during these drug-induced fits [apomorphine actually has an anorexic effect (9)], the pecking exhibited is closely similar to that shown during feeding If small contrastıng visual stimuli are offered in the test environment the pecks tend to be directed at these, the targets also augment the frequency of peckıng $(2,5)$ Pigeons will, however, also exhibit apomorphine-induced pecking in total darkness (own observations)

In a previous study (12) it was shown that apomorphinetriggered peckıng of pigeons conditions classically to the particular environment in which it was initially induced That is, a visually salient cage acted as a conditioned stimulus (eliciting a conditoned peckıng response) when it had previously been associated with apomorphine injections as unconditioned stimuli (which elicited an unconditioned pecking response) [for reviews on the conditioning of drug effects see $(18,19)]$. In the present study we investigate the possibility that the sensitization that is noticeable upon repeated apomorphine injections may at least partly be due to such Pavlovian conditioning We also follow up incidental obser- vations suggesting that such conditioning additionally involves the development of a positive, appetitive attachment to the apomorphine-related environment

\section{SENSITIZATION}

It has been reported for several species that upon repeated injections the same dose of apomorphine induces an increasıngly stronger behavioural response [mice $(6)$, rats $(4,15)$ pigeons $(2,7)]$ In this experiment we investigated whether the sensitization observed in pigeons could be due to classical conditioning If so, it should occur when the repeated apomorphine injections take effect in the same environment, but not if they do so in differing environments Since, however, it is known that environmental novelty/familiarity by itself influences the behavioral effects of apomorphine $(16,19)$, care must be taken to ensure that the critical test environment is equally novel/familar to control and experimental subjects

\section{Method}

Thirty-two adult homing pigeons (Columba livia) of local stock, weighing between 450 and $550 \mathrm{~g}$, were used They had no prior drug expenence and were normally kept in individual galvanized wire mesh cages with food and water freely available in a well-ventilated and brightly-lit anımal room The subjects were divided at random into 4 groups of 8 (groups A, B, C, D). Two different experımental cages $(45 \times 40 \times 35 \mathrm{~cm})$ were used one had 
TABLE 1

DESIGN OF THE SENSITIZATION/TOLERANCE EXPERIMENT

\begin{tabular}{lccc}
\hline Condition & Group & \multicolumn{1}{c}{ Day 1,2 } & Day 3 \\
\hline $\begin{array}{c}\text { Same } \\
\text { Cage }\end{array}$ & A & $\begin{array}{l}\text { sal white/green } \\
\text { apo black/yellow } \\
\text { sal black/yellow } \\
\text { apo white/green }\end{array}$ & apo black/yellow \\
$\begin{array}{c}\text { Different } \\
\text { Cage }\end{array}$ & B & $\begin{array}{l}\text { sal white/green } \\
\text { apo black/yellow } \\
\text { sal black/yellow } \\
\text { apo white/green }\end{array}$ & apo white/green \\
\hline
\end{tabular}

Pigeons experienced the effect of either saline (sal) or apomorphine (apo ) in either a black/yellow or a white/green cage Pecking in response to apomorphine was recorded on days 2 and 3

three side walls and the ceiling lined with white cardboard peppered with green dots ( $8 \mathrm{~mm}$ diameter, 10 dots per sq diam ) The other cage had the same surfaces lined with black cardboard peppered with yellow dots (size and density as before)

The experiment took place on 3 consecutive days The design is outlined in Table 1 it controlled for possible cage familiarizaton and color effects On day 1 half of the pigeons (groups $\mathrm{A}$ and B) were injected intramuscularly with salıne $(09 \% \mathrm{NaCl}, 05 \mathrm{ml})$ and placed in the white/green cage for half an hour After they were removed from that cage they were injected with apomorphine $(05 \mathrm{mg} / \mathrm{kg}$ body weight, about $025 \mathrm{ml} \mathrm{IM}$, a suboptımal dose was chosen to avold a ceiling effect) and placed in the black/yellow cage for half an hour The other half of the pigeons (groups $\mathrm{C}$ and D) was treated in the same way, except that they were placed in the black/yellow cage while salıne treated and in the white/green cage while apomorphine treated Afterwards the subjects were returned to their home cages

The procedure on day 2 was exactly the same as on day 1 except that for the first $15 \mathrm{~min}$ the pecks after apomorphine treatment (black/yellow cage for groups A and B, white/green cage for groups $\mathrm{C}$ and $\mathrm{D}$ ) were recorded by an observer from an adjacent room through a one-way viewing partition

On day 3 all pigeons were injected with apomorphine Pigeons belonging to groups $\mathrm{A}$ and $\mathrm{C}$ were placed in the same cage in which they had experienced apomorphine on days 1 and 2 These 2 groups thus experienced the same environment while apomorphine treated throughout the experıment Pigeons of groups B and D were placed in the cage to which they had been exposed after salıne injections on days 1 and 2 Thus, the environment these subjects experienced under apomorphine on day 3 differed from the one they had experienced while drugged on days 1 and 2 The number of pecks emitted during $15 \mathrm{~min}$ in the relevant cages was counted The observer who scored the peckıng was not informed as to which treatment the individual pigeons had previously received, though he was otherwise experienced in sconing apomorphine-induced peckıng

\section{Results}

The numbers of pecks issued under the influence of apomorphine on days 2 and 3 by each of the 32 pigeons are shown in Table 2 Most of these pecks were directed at the spots on the walls of the experimental cages The difference scores for day 3 are the increases or decreases relative to the day 2 counts (Table 2) Expressed in terms of percentage difference relative to day 2
TABLE 2

PECKING RESPONSES (PER IS MIN) OF PIGEONS INJECTED WITH APOMORPHINE IN THE SAME AND IN DIFFERENT CAGES ON DAYS 2 AND 3

\begin{tabular}{|c|c|c|c|c|c|}
\hline Conditioning & Group & Pigeons & $\begin{array}{l}\text { Pecks } \\
\text { Day } 2\end{array}$ & $\begin{array}{l}\text { Pecks } \\
\text { Day } 3\end{array}$ & Difference \\
\hline & & 1 & 1596 & 1805 & +209 \\
\hline & & 2 & 1722 & 2052 & +330 \\
\hline & & 3 & 139 & 572 & +433 \\
\hline & A & 4 & 1263 & 1319 & +56 \\
\hline & & 5 & 765 & 938 & +173 \\
\hline & & 6 & 2 & 22 & +20 \\
\hline & & 7 & 143 & 898 & +755 \\
\hline Same & & 8 & 716 & 769 & +53 \\
\hline \multirow[t]{16}{*}{ Cage } & & 17 & 1717 & 2161 & +444 \\
\hline & & 18 & 2859 & 2642 & -217 \\
\hline & & 19 & 1466 & 950 & -516 \\
\hline & C & 20 & 2453 & 2440 & -13 \\
\hline & & 21 & 217 & 241 & +24 \\
\hline & & 22 & 1781 & 2307 & +526 \\
\hline & & 23 & 448 & 2841 & +2393 \\
\hline & & 24 & 819 & 1115 & +296 \\
\hline & Means & $s=s \mathrm{~d}$ & $1132 \pm 834$ & $1442 \pm 857$ & $+310 \pm 613$ \\
\hline & & 9 & 1496 & 188 & -1308 \\
\hline & & 10 & 2451 & 498 & -1953 \\
\hline & & 11 & 1338 & 412 & -926 \\
\hline & B & 12 & 422 & 859 & +437 \\
\hline & & 13 & 738 & 23 & -715 \\
\hline & & 14 & 396 & 266 & -130 \\
\hline & & 15 & 395 & 216 & -179 \\
\hline Different & & 16 & 2152 & 93 & -2059 \\
\hline \multirow[t]{9}{*}{ Cage } & & 25 & 1668 & 1888 & +220 \\
\hline & & 26 & 209 & 666 & +457 \\
\hline & & 27 & 1316 & 0 & -1316 \\
\hline & D & 28 & 1292 & 657 & -635 \\
\hline & & 29 & 246 & 351 & +105 \\
\hline & & 30 & 549 & 1095 & +546 \\
\hline & & 31 & 970 & 365 & -605 \\
\hline & & 32 & 1589 & 1551 & -38 \\
\hline & Means & $\pm s d$ & $1077 \pm 671$ & $570 \pm 525$ & $-506 \pm 804$ \\
\hline
\end{tabular}

the mean increase of groups $\mathrm{A}$ and $\mathrm{C}$ combined (apomorphine in constant environment) was $+273 \%$, whereas the mean decrease for group B and D combined (apomorphine in nonconstant environment) was $-469 \%$ Both the increase and the decrease were significant (Wilcoxon, $p<001$ and $p<005$ ) The difference between the two main treatments was similarly significant (MannWhitney, $p<001$ ) The specific kınd of environment (different cage colours) expenenced under apomorphine and salıne may have interacted the difference between the day 2 to day 3 difference scores of groups A and B is more marked, though not significantly so, than that between the difference scores of groups C and D

Casual observations incidentally confirmed (see Introduction) that, when injected with salıne, pigeons peck, if at all, less than a dozen times per $15 \mathrm{~min}$

\section{Discussion}

The results demonstrate that the apomorphine-induced re- 
sponse of pigeons increases when they twice experience the same environment while under the influence of the drug. The response of pigeons placed in two different environments while under the influence of apomorphine tends to decrease, indicatıng a development of tolerance to the drug The result accords with the hypothesis that sensitization to apomophine in pigeons is dependent on environmental constancy The corresponding successive increases in response to a standard dose of the drug are thus attributed to a learning effect. A pecking tendency that is classically conditioned to environmental cues (12) enhances the peckıng that is pharmacologically induced by the drug, an unconditioned response The excitatory conditioned response shown by the experimental groups was clearly strong enough to counteract the response decrement shown by the control groups

Incidentally, this latter unexpected tolerance-like effect could possibly be due to an inhibitory response or state, that conditioned to the saline cages during the two initial sessions Separate and differently designed experiments are yet needed to support this tentative suggestion At present, it is more realistic to assume that the tolerance we observed was of purely pharmacological ongin Regardless of this, it is important to stress again that the design of the present experiment ensured that the nonconstant environment treatment did not involve an exposure to a novel environment Both the control and experimental pigeon groups had equivalent previous experience with the test cages that were used upon the third and critical apomorphine injection. Thus, differential habituation/familiarization to the test environments cannot be made responsible for the main result, the sensitization to apomorphine that we report

It may be that the two types of test environments were not exactly equivalent in supporting sensitization in that the yellow/ black cage yielded a larger effect than the white/green cage In the context of conditioning it is not an uncommon finding that conditioned stimuli differ in effectiveness Previously, however, it was found that the white/green cage was slightly more effective in that respect than the yellow/black cage (12) Chance sampling effects are thus a more likely explanation

\section{PLACE PREFERENCE I}

Lindenblatt and Delius (12) considered the possibility that apomorphine may act as a reinforcer in pigeons Incidental observations (11) had suggested that pigeons placed in an environment where they had previously experienced the drug showed signs of being more at ease, more relaxed, and less intent on fleeing than pigeons that had previously experienced the same environment under salıne. The rewarding action of several drugs including apomorphine $(3,14,16)$ has, of course, been amply demonstrated in mammals, but as far as we are aware no such effects have been reported for birds, despite the fact that pigeons are popular as subjects for psychopharmacological experiments As a step towards demonstrating a rewarding effect of apomorphine in pigeons we asked whether it would induce place preferences

\section{Method}

Twelve pigeons of the same kind as those used in Experiment I served as subjects They were kept as previously described, except that they were maintained food deprived to $80 \%$ of their normal weights The T-maze schematically depicted in Fig 1 was used. The stem alleyway was constructed of dark brown hardboard and had a trap door at the start end A hose connected to an air compressor terminated below the door At the far end the tunnel opened sidewards into two goal-cages The inner, back and side

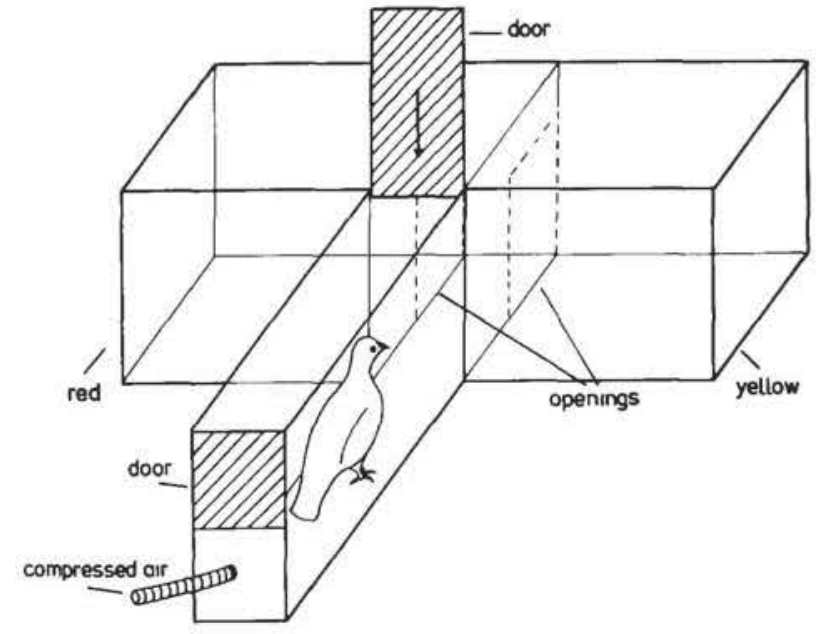

FIG 1 Schematic plan of the T-maze used for the place preference experiments

walls of these cages were made of hardboard, the cellıng and front wall were constructed of wiremesh The intenor of the left cage was painted red, that of the nght cage was painted yellow Two 60 -W light bulbs were suspended $20 \mathrm{~cm}$ above the cellings of the cages

The animals were familiarized with the two goal-cages on day 1 by placing them successively into the red cage and into the yellow cage for one hour each (Table 3 ). On day 2 the procedure was repeated in the reverse order. The openings of the alleyway were kept shut and the pigeons were given $5 \mathrm{~g}$ of grain in each cage during these sessions The subjects were then divided into four equal groups (A, B, C, D) of 3 pigeons Subjects belonging to group $A$ were injected with apomorphine $(1 \mathrm{mg} / \mathrm{kg} \mathrm{IM}$, about $05 \mathrm{ml}$ ) and placed in the yellow cage for an hour on day 3 On day 4 they were injected with salıne $(05 \mathrm{ml} \mathrm{IM})$ and placed in the red cage for an hour Subjects belonging to group B were placed in the yellow and red cages in the same order but were injected with saline on day 3 and with apomorphine on day 4 Group $C$ birds were placed into the cages in reverse order to group B but injected in the same way as group A Group D subjects finally experienced the cages in the same order as group $C$ but were injected the same way as group B The treatments of each group were repeated in precisely the same way on days 5 and 6 , and again on days 7 and 8 Thus, each pigeon consistently experienced one color cage while under the influence of apomorphine and the other color cage while under the influence of saline according to a balanced experimental design

Choice tests were conducted on days $9,12,15,19$, and 22 No injections were given Each pigeon was placed into the start end of the alleyway The experimenter left the room and observed from an adjacent room through a one-way screen A choice was recorded when the pigeons entered one or the other of the two goal-cages If the animals did not leave the alleyway withın 5 min the compressed arr was turned on to force a choice After the pigeons entered the cage of their choice they were immediately removed and placed again at the start of the maze On each test day each pigeon completed 10 choice trials

\section{Results}

When injected with apomorphine during training all pigeons experienced a peckıng fit as described earlier Salıne injections had no particular effect Table 4 summarizes the choice behavior 
TABLE 3

DESIGN OF PLACE PREFERENCE EXPERIMENT 1

\begin{tabular}{|c|c|c|c|c|c|}
\hline \multirow[t]{2}{*}{ Groups } & \multirow[b]{2}{*}{ Days } & \multicolumn{2}{|c|}{ Familianzed } & \multirow{2}{*}{$\begin{array}{c}\text { Tranıng } \\
3,5,7 \quad 4,6,8\end{array}$} & \multirow{2}{*}{$\begin{array}{c}\text { Test } \\
9,12,15,19,22\end{array}$} \\
\hline & & 1 & 2 & & \\
\hline A & & R Y & Y R & $\mathrm{R}$ apo $\mathrm{Y}$ sal & \\
\hline B & & R Y & Y R & $Y$ sal $R$ apo & $\begin{array}{l}\mathrm{R} \\
\text {, }\end{array}$ \\
\hline C & & R Y & Y R & $\mathrm{Y}$ apo $\mathrm{R}$ sal & $\mathrm{Y}$ \\
\hline D & & R Y & Y R & $\mathrm{R}$ sal $\mathrm{Y}$ apo & \\
\hline
\end{tabular}

Pigeons were first familarized with goal cages ( $R$ red, $Y$ yellow) then trained by placing them in the cages while injected with apomorphine (apo ) or salıne (sal ) and finally tested for cage preference

of the pigeons during the subsequent 50 test trials It is apparent that every single pigeon preferred the colored goal-cage that it had experienced while injected with apomorphine during training (binomial, $p<001$ )

A somewhat stronger preference might have developed for the $\mathrm{red} /$ left cage When that cage was positive ( $1 \mathrm{e}$, experienced under apomorphine during training) it was chosen on 412 occasions while when the yellow/right cage was posituve it was chosen on only 357 occasions The preference that developed for the positive cage (regardless now of its color/position) might have been stronger when the animals had been exposed to it (under apomorphine) first durıng the training sessions (groups $\mathrm{A}$ and $\mathrm{C}$ 407 choices correct) rather than second (groups B and D 362 choices correct) Both these latter effects are however not statistically significant

Over the 5 testıng days there was only a mınor, insıgnificant decay in preference ( $F_{1}$ 2) However, the number of unforced cholces (without use of compressed air) dropped steeply from an average 70 out of 10 trials on the first test session to an average 19 on the fifth session

\section{Discussion}

The results clearly demonstrate that when pigeons have to

TABLE 4

GOAL-CAGE CHOICES OF UNTREATED PIGEONS PREVIOUSLY EXPOSED TO DIFFERENT CAGES (RED, YELLOW) WHILE UNDER THE INFLUENCE OF APOMORPHINE (apo ) OR SALINE (sal)

\begin{tabular}{|c|c|c|c|c|}
\hline Training & Group & Pigeon & $\begin{array}{l}\text { Apo } \\
\text { Cage }\end{array}$ & $\begin{array}{l}\text { Sal } \\
\text { Cage }\end{array}$ \\
\hline \multirow{6}{*}{$\begin{array}{l}\text { apo red/ } \\
\text { sal yell }\end{array}$} & \multirow{3}{*}{ A } & 1 & 45 & 5 \\
\hline & & 2 & 47 & 3 \\
\hline & & 3 & 38 & 12 \\
\hline & \multirow{3}{*}{ B } & 4 & 37 & 13 \\
\hline & & 5 & 41 & 9 \\
\hline & & 6 & 39 & 11 \\
\hline \multirow{7}{*}{$\begin{array}{c}\text { apo yell / } \\
\text { sal red }\end{array}$} & \multirow{3}{*}{ C } & 7 & 38 & 12 \\
\hline & & 8 & 39 & 11 \\
\hline & & 9 & 37 & 13 \\
\hline & \multirow{3}{*}{ D } & 10 & 34 & 16 \\
\hline & & 11 & 29 & 21 \\
\hline & & 12 & 37 & 14 \\
\hline & \multicolumn{2}{|c|}{ means $\pm s d$} & $384 \pm 45$ & $117 \pm 45$ \\
\hline
\end{tabular}

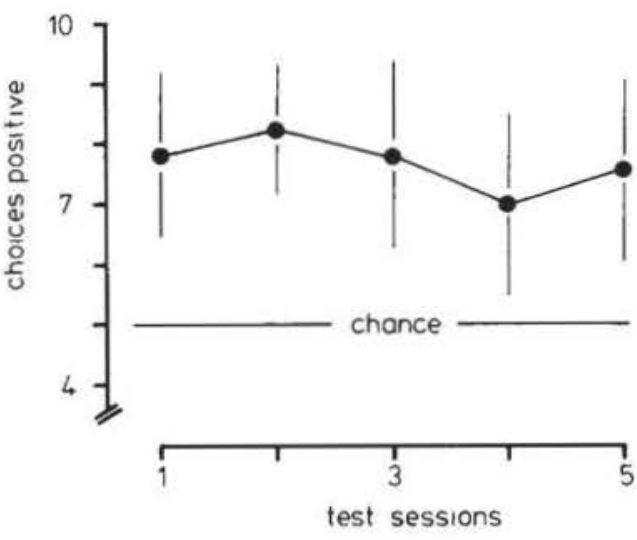

FIG 2 Mean goal-cage choices (with standard deviations) of pigeons during the successive test sessions of the first place preference expenment Choices positive choices of the cage previously associated with apomorphine treatment

choose they prefer the environment they previously experienced while under the effect of apomorphine rather than the environment they experienced when injected with salıne However, in this experiment the subjects often did not actively seek the preferred goal-cage The immediate removal from the cage of their choice probably had an aversive effect which inhibited subsequent choice behavior

\section{PLACE PREFERENCE II}

Even though all pigeons in the preceding experiment preferred to enter the cage to which they had been exposed while injected with apomorphine during training they did not always choose spontaneously Observations suggested that this might have been due to a number of unfavourable but incidental methodological details The design of the following experiment was modified to correct these so as to facilitate unforced choices

\section{Method}

Twelve pigeons were used They were housed and deprived as before The stem tunnel of the T-maze described in the Method section of the previous experiment was shortened The inside of the alleyway was painted matt black Furthermore, the start-box was separated from the tunnel with a vertical gullotine door The light bulbs slluminating the goal cages were hung lower down and $20 \mathrm{~cm}$ before the front wire-mesh walls of these cages

The familiarization (days 1 and 2 ) and training (days 3 to 8 ) procedures were an exact replication of those described for the preceding Experıment 1 Choice tests took place on days 9 through 15 Only 2 trals per day were conducted For a given tral the pigeon was placed into the dark start-box and left there for $2 \mathrm{~min}$ Then the guillotine door was opened and the choice behavior of the pigeon was observed from the adjacent room No compressed air was used The spontaneous cholces were recorded as before The pigeons were left in the goal-cage of their choice for $5 \mathrm{~min}$ before being removed

Results

All pigeons on all occasions chose one of the goal-cages within 10 min (mean latency $35 \mathrm{~min}$ ) Therr choices are summarized in Table 5 Each pigeon showed an overall preference for the cage it had expenenced while injected with apomorphine (binomial, 
TABLE 5

GOAL-CAGE CHOICES OF UNTREATED PIGEONS THAT HAD PREVIOUSLY EXPERIENCED DIFFERENT CAGES (RED, YELLOW) WHILE UNDER THE INFLUENCE OF APOMORPHINE (apo ) AND SALINE (sal )

\begin{tabular}{|c|c|c|c|c|}
\hline Condition & Group & Pigeon & $\begin{array}{l}\text { Apo } \\
\text { Cage }\end{array}$ & $\begin{array}{l}\text { Sal } \\
\text { Cage }\end{array}$ \\
\hline \multirow{6}{*}{$\begin{array}{l}\text { apo red/ } \\
\text { sal yell }\end{array}$} & \multirow{3}{*}{ A } & 1 & 12 & 2 \\
\hline & & 2 & 13 & 1 \\
\hline & & 3 & 9 & 5 \\
\hline & \multirow{3}{*}{ B } & 4 & 9 & 5 \\
\hline & & 5 & 11 & 3 \\
\hline & & 6 & 12 & 2 \\
\hline \multirow{7}{*}{$\begin{array}{l}\text { apo yell / } \\
\text { sal red }\end{array}$} & \multirow{3}{*}{ C } & 7 & 11 & 3 \\
\hline & & 8 & 11 & 3 \\
\hline & & 9 & 12 & 2 \\
\hline & \multirow{3}{*}{ D } & 10 & 11 & 3 \\
\hline & & 11 & 11 & 3 \\
\hline & & 12 & 11 & 3 \\
\hline & \multicolumn{2}{|c|}{ mean $\pm s d$} & $102 \pm 14$ & $29 \pm 11$ \\
\hline
\end{tabular}

$p<0.01)$. Most, incidentally, also exhibited conditıoned peckıng as described by Lindenblatt and Dehus (12) when in the positive goalbox As before, the pigeons that were first injected with apomorphine (groups A and C) showed on average a slightly, though not significantly, stronger goal-cage preference than those first injected with salıne (groups B and D) There was no significant difference in preference between the pigeons for whom the red cage was positive and those for whom the yellow cage was positive Furthermore, the average preferences as in the previous experiment remained virtually constant over the 7 testing sessions

\section{Discussion}

This experiment confirmed that pigeons develop a preference, lasting for at least 14 days, for an environment to which they had been repeatedly exposed while under the influence of apomorphine, and that they actively seek it out The preference cannot have been determined by novelty/familiarity factors since during familianzation and training subjects were equally often exposed to both goal cages

\section{GENERAL DISCUSSION}

The results of the first experiment support the hypothesis that the sensitization that is commonly observed in pigeons with the first few injections of the drug apomorphine is at least partly due to classical conditioning Increased pecking was observed when pigeons were placed in the environment where they had been injected repeatedly with apomorphine Such an increase was absent if they experienced different environments after drug injections There was, in fact, a decrease in pecking in that context that is assumed to be due to the development of tolerance In a previous report (12) it has been shown that environments that elicit conditioned pecking responses after having been associated with apomorphine injection are effective as conditioned stimuli We assume that the response increase observed here is due to the addition of a conditioned response elicited by the environment to the direct unconditioned response elicited by the drug itself The sensitization effect that is regularly observed in pigeons upon repeated injections of a standard dose of apomorphine $(2,6)$ is thus at least partially ascribable to a classical conditioning effect In mammals such a mechanism is thought to apply to the sensitization to several drugs $(18,19)$ Obviously the behavioral effect does not preclude the existence of pharmacological sensitization mechanisms, a synergism of both may in fact be common

The demonstration, provided by the second and third exper1ments, that pigeons develop a persistent place preference for an environment which they expenenced under apomorphine, establishes that the drug indeed acts as an appetitive unconditioned stımulus A similar effect of apomorphine has been described for rats (17) These findings are in line with the notion that the drug is effective as a reinforcer in the context of conditioning That has in fact been demonstrated for rats and monkeys which self-injected apomorphine when given a chance to do so $(3,21)$ No such evidence is avallable for birds, but in pigeons it has been found that apomorphine is effective in eliciting pecking when injected into the nucleus basalıs prosencephalı (13) This nucleus is one among several avian brain structures which supports electrical self-stımulation (22) More generally, as in mammals [(20), see also (10)] neural reinforcement substrates in birds seem to be associated with dopamine content and/or receptivity (8) We suggest that in our experiments apomorphine as a dopaminergic drug activated these reward mediating structures This hypothesis will be tested more directly in further experiments

\section{ACKNOWLEDGEMENTS}

The research was supported by a grant from the Deutsche Forschungsgemeinschaft We thank Dagmar Hagenkotter, Barbara Borzel and Martina Siemann for preparing the manuscript, Julıa Delius for editıng it, Angela Franchinı and Martina Siemann for draftung the figures and Drs Clive Wynne and Jacky Emmerton for polishing the English and some useful suggestions

\section{REFERENCES}

1 Amsler, C Beitrage zur Pharmakologie des Gehırns Arch Exp Pathol Pharmakol 97 1-27, 1923

2 Basten-Kreft, A Apomorphin-induziertes Verhalten bei Tauben Diplomarbett Ruhr-Universitát Bochum 1977

3 Baxter, B L, Gluckman, M J, Stein, L, Scern, R A Selfinjection of apomorphine in the rat Positive reinforcement by a dopamine receptor stumulant Pharmacol B1ochem Behav 2387392,1974

4 Bevan, P Repeated apomorphine treatment causes behavioural supersensitivity and dopamine D2 receptor hyposensitivity Neurose1 Lett 35 185-189, 1983

5 Brunell, M, Magnı, F, Moruzzi, G, Musumec1, D Apomorphine pecking in the pigeon Arch Ital Biol 113 303-325, 1975

6 Costentin, J, Protais, P, Schwartz, J C Rapid and dissociated changes in sensitivities of different receptors in mouse brain Nature
$257405-407,1975$

7 Delius, J D The peck of the pigeon, free for all In Lowe, C F, Richelle, M, Blackman, D E, Bradshaw, C M, eds Behaviour analysis and contemporary psychology New York Erlbaum 1985 53-81

8 Delius, J D, Pellander, K Hunger dependence of electncal brain self-stumulation in the pigeon Physiol Behav 28 63-66, 1982

9 Deviche, P Administration of small doses of apomorphıne attenuates feeding in non-deprived pigeons Physiol Behav 33 581-585, 1984

10 Gratton, A, Hoffer, B J, Gerhardt, G A Effects of electrical stimulation of brain reward sites on release of dopamine in rat An in vivo electrochemical study Brain Res Bull 21 319-324, 1988

11 Lindenblatt, U Die dopaminerge Auslosung des Pickverhaltens be Tauben Dissertation, Ruhr-Universitat Bochum, 1986

12 Lindenblatt, U, Dehus, J D Apomorphine-induced pecking in 
pigeons classically conditioned to environmental cues Psychopharmacology (Berlın) 93 223-225, 1987

13 Lindenblatt, U, Dehus, J D Nucleus basalıs prosencephalı, a substrate of apomorphine-induced pecking in pigeons Brain Res $4531-8,1988$

14 Machlis, L Apomorphine Effects on the tuming and sequencing of pecking behavior in chicks Pharmacol Biochem Behav 13331 336, 1980

15 Mattingly, B A, Gotsıck, J E, Salamanca, K Latent sensitization to apomorphine following repeated low doses Behav Neurosci $102553-558,1988$

16 Mazurskı, E J , Benınger, R J Stımulant effects of apomorphıne and (+)-amphetamine in rats with varied habituation to test environment Pharmacol Bıchem Behav 29 249-255, 1988

17 van der Kooy, D, Swerdlow, N R, Koob, G F Paradoxical reinforcing properties of apomorphine Effects of nucleus accumbens and area postrema lesıons Brain Res 259 111-118, 1983

18 Schiff, S R Conditioned dopaminergic activity Biol Psychiatry $17135-154,1982$

19 Siegel, S Pharmacological habituation and learning In Commons, M L , Herrnstein, R I , Wagner, A R, eds Quantitative analyses of behavior III Acquisition Cambridge, MA Ballınger, 1982 195-217

20 Wise, R A Neuroleptics and operant behaviour The anhedonia hypothesis Behav Brain Scı 5 39-87, 1982

21 Woolverton, W L. Goldberg, L I, Ginos, J Z Intravenous self-administration of dopamine receptor agonists by rhesus monkeys J Pharmacol Exp Ther 230 678-683, 1984

22 Zeigler, H P. Hollard, V D. Wild, J M, Webster, D M Intracranial self-stimulation from endbrain nuclei in the pigeon Physiol Behav 21 387-394, 1978 